\title{
Novel Orthopoxvirus and Lethal Disease in Cat, Italy
}

\author{
Gianvito Lanave, Giulia Dowgier, Nicola Decaro, Francesco Albanese, Elisa Brogi, Antonio Parisi, \\ Michele Losurdo, Antonio Lavazza, Vito Martella, Canio Buonavoglia, Gabriella Elia
}

We report detection and full-genome characterization of a novel orthopoxvirus (OPXV) responsible for a fatal infection in a cat. The virus induced skin lesions histologically characterized by leukocyte infiltration and eosinophilic cytoplasmic inclusions. Different PCR approaches were unable to assign the virus to a defined OPXV species. Large amounts of typical brick-shaped virions, morphologically related to OPXV, were observed by electron microscopy. This OPXV strain (Italy_09/17) was isolated on cell cultures and embryonated eggs. Phylogenetic analysis of 9 concatenated genes showed that this virus was distantly related to cowpox virus, more closely related to to ectromelia virus, and belonged to the same cluster of an OPXV recently isolated from captive macaques in Italy. Extensive epidemiologic surveillance in cats and rodents will assess whether cats are incidental hosts and rodents are the main reservoir of the virus. The zoonotic potential of this novel virus also deserves further investigation.

$\mathrm{O}$ rthopoxviruses (OPXVs; family Poxviridae, subfamily Chordopoxvirinae, genus Orthopoxvirus) are complex, double-stranded DNA viruses with ongoing interest because of their potential use as bioterrorism agents and in gene therapy. Variola virus (VARV), the causative agent of smallpox, has been eradicated in nature; however, there is still the possibility of accidental or intentional release, and it is currently classified as a category A biologic agent (1). Another concern is the zoonotic potential of some OPXVs, such as monkeypox virus, camelpox virus, buffalopox virus, and cowpox virus (CPXV) $(2,3)$.

$\mathrm{CPXV}$, which has a wide host range and a distribution restricted to the Eurasian continent, causes localized dermatitis in humans, although severe disease might develop in immuneocompromised persons, occasionally with a fatal

Author affiliations: University of Bari, Valenzano, Italy (G. Lanave,

G. Dowgier, N. Decaro, M. Losurdo, V. Martella, C. Buonavoglia,

G. Elia); La Vallonea Veterinary Laboratory, Milan, Italy

(F. Albanese); Centro Veterinario Montarioso, Siena, Italy

(E. Brogi); Istituto Zooprofilattico Sperimentale di Puglia e Basilicata,

Putignano, Italy (A. Parisi); Istituto Zooprofilattico Sperimentale di

Lombardia ed Emilia Romagna, Brescia, Italy (A. Lavazza)

DOI: https://doi.org/10.3201/eid2409.171283 outcome. Natural hosts for CPXV are wild rodents (4), but the infection is acquired mainly through direct contact with cats, which are natural hosts, and rarely by exotic animals and wild species (5). Ectromelia virus (ECTV) is the causative agent of mousepox, a severe exanthematous disease of mice in laboratory colonies and has been reported worldwide in several outbreaks and causes high economic losses in biomedical research (6). ECTV has never been reported in humans, and little is known regarding its natural distribution and hosts (7).

Reports of OPXV infections in animals and humans have largely increased during recent decades, which has enhanced their zoonotic potential and led to the perception of an increasing risk for humans (8). For cats, there are several reports of poxvirus infections, but the causative agent has been characterized as CPXV (9-14) or has not been characterized (15-18).

We report a case of fatal infection with an OXPV in a household cat. This virus was more closely related to ECTV than to CPXV, putatively representing a novel OPXV species.

\section{Materials and Methods}

\section{Case Study}

A domestic, short-haired, male, 6-month-old cat was brought to a veterinarian because of multicentric, nodular, ulcerative dermatitis (Figure 1). The cat was regularly vaccinated for common feline diseases (feline panleukopenia, rhinhotracheitis, calicivirosis, and chlamydiosis) and showed negative test results for retroviral infections. An antiparasitic product had been applied monthly (Frontline Combo Spot On; Merial, Ingelheim, Germany). The cat was fed a balanced commercial diet and lived indoors, but it had access to outdoors and had a hunting behavior.

The cat had multiple nodular, plaque-like, ulcerative lesions on its body, particularly on the feet and face. Results of diagnostic testing, including a wood lamp examination, skin scrapings, trichogram, and fungal culture, were negative. Cytological examination showed a mixed inflammatory population of cells with a relevant amount of 

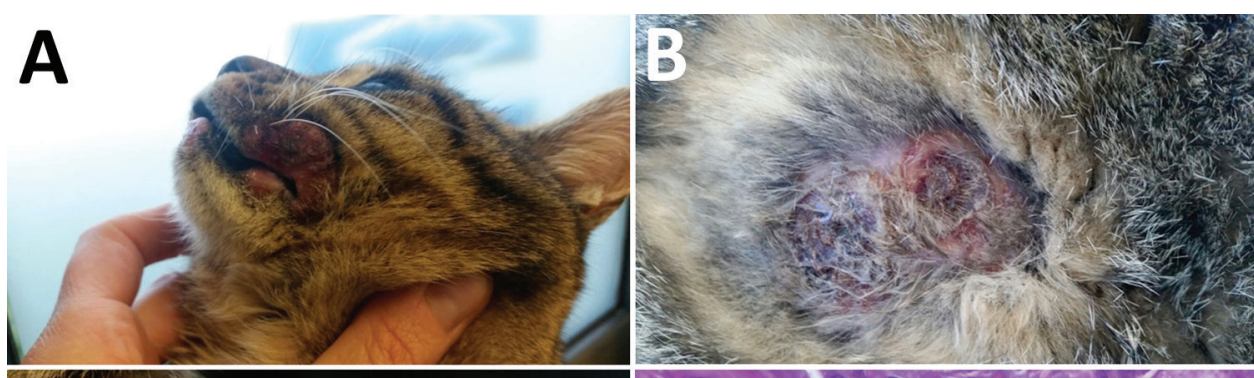

Figure 1. Cat with orthopoxvirus infection, Italy. Ulcerated nodules and plaques were observed on the lips (A), thorax (B), and forelimb (C). Skin punch biopsy specimen (D) showing leukocyte infiltration and cytoplasmic inclusion bodies (arrows) (hematoxylin
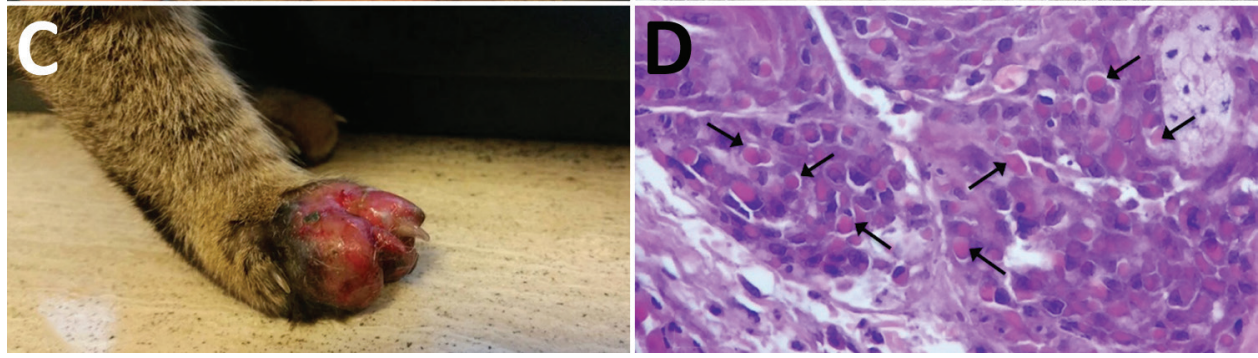

and eosin stain, original magnification $\times 60$ ).

eosinophils. A blood test showed only a mild leukocytosis with an increase in numbers of lymphocytes, neutrophils, and eosinophils. Because of rapid worsening of its clinical conditions, the cat was euthanized.

\section{Histopathologic Analysis}

We collected multiple skin biopsy specimens for histopathologic analysis by using an 8-mm biopsy punch and fixed these specimens in $10 \%$ buffered formalin. Samples were embedded in paraffin, sectioned, and stained with hematoxylin and eosin, according to standard protocols.

\section{DNA Extraction and PCR Amplification}

An OPXV infection was suspected on the basis of clinical presentation and histopathologic analysis. Therefore, we processed histologic preparations for molecular investigations to confirm the presumptive diagnosis. We purified total DNA from a thin section of $\approx 20 \mathrm{mg}$ of formalin-fixed, paraffin-embedded tissue by using the DNeasy Blood and Tissue Kit (QIAGEN, Hilden, Germany) according to the manufacturer's instructions.

We tested the DNA extract by using 2 panchordopoxvirus PCRs specific for the variable GC content of the genera included in the subfamily Chordopoxvirinae and other unclassified chordopoxviruses (19). For the low GC content PCR, we used DNA from a laboratory vaccinia virus Western Reserve strain (VACV-WR) as a positive control. For the high GC content PCR, we used an Orf virus isolated during an outbreak of contagious ecthyma as a positive control. We initially conducted subsequent identification of OPXV by using a PCR specific for the gene coding A-type inclusion protein (20), followed by a second PCR specific for the hemagglutinin (HA) gene (21). In addition, we performed 2 species-specific PCRs, 1 for ECTV and 1 for CPXV, to further characterize the virus (22).
We conducted all PCR amplifications by using an LA PCR Kit (version r.2.1) (Takara Bio, Tokyo, Japan) in a $50-\mu \mathrm{L}$ reaction containing $1 \mathrm{mmol} / \mathrm{L}$ of primers, LA PCR Buffer $\left(\mathrm{Mg}^{2+}\right), 8 \mu \mathrm{L}$ of dNTP mixture (corresponding to $400 \mathrm{mmol} / \mathrm{L}$ of each dNTP), 2.5 units of TaKaRa LA Taq polymerase, and $1 \mu \mathrm{L}$ of template DNA. The cycling protocol used for each assay was programmed as described (19). PCR products were subjected to electrophoresis on a $1.5 \%$ agarose gel containing a fluorescent nucleic acid marker (GelRed; Bio-Rad Laboratories, Hercules, CA, USA) at 80 $\mathrm{V}$ for $45 \mathrm{~min}$ and visualized under fluorescent light on the Gel Doc EZ Imaging System with Image Laboratory Software (Bio-Rad Laboratories). PCR products were directly sequenced by Eurofins Genomics GmbH (Ebersberg, Germany). We manually edited and analyzed sequences by using the Geneious platform version 10.1.3 (Biomatters Ltd., Auckland, New Zealand).

\section{Virus Isolation}

After diagnosis of OPXV infection, we collected additional biopsy specimens from skin lesions of the diseased cat intravitam and then used for subsequent virologic investigations. For virus isolation, we used African green monkey kidney fibroblast CV-1 cells and African green monkey kidney epithelial Vero cells. Cells were grown in Dulbecco's modified minimum essential medium (DMEM) supplemented with $10 \%$ fetal bovine serum. Tissues were homogenized in DMEM $(10 \%$, wt $/ \mathrm{vol})$ and centrifuged at $8,000 \times g$ for $10 \mathrm{~min}$. Supernatants were treated with antimicrobial drugs (penicillin 5,000 IU/mL, streptomycin $2,500 \mu \mathrm{g} / \mathrm{mL}$, and amphotericin B $10 \mu \mathrm{g} / \mathrm{mL}$ ) for $30 \mathrm{~min}$, inoculated on partially confluent CV-1 and Vero cell cultures, and incubated at $37^{\circ} \mathrm{C}$ in a $5 \% \mathrm{CO}_{2}$ incubator. After an adsorption period of $45 \mathrm{~min}$, DMEM was added. Cells were observed daily for cytopathic effects. 
For hematoxylin and eosin staining and indirect immunofluorescence (IIF) assay, we grew cells on coverslips placed in 12-well plates. Cells were mock- or virus-infected and coverslips were harvested at 48 hours postinfection. For detection of inclusion bodies, we fixed cells in Bouin solution for $2 \mathrm{~h}$ and stained them with hematoxylin and eosin. For the IIF assay, cells were fixed with $80 \%$ acetone for 30 min. Coverslips were rinsed twice with phosphate-buffered saline and incubated $30 \mathrm{~min}$ in a humidified chamber at $37^{\circ} \mathrm{C}$ with a serum sample (diluted 1:50) collected from the ill cat. Coverslips were washed twice with phosphate-buffered saline and incubated with goat anti-cat IgG conjugated with fluorescein isothiocyanate (Sigma-Aldrich, Milan, Italy).

The homogenate of skin biopsy specimens was inoculated onto the chorioallantoic membrane of 12-day-old chick embryos. After 2 days of incubation at $37^{\circ} \mathrm{C}$, membranes were collected from the eggs and pock morphology was observed.

\section{Electron Microscopy}

We performed negative staining and electron microscopic analysis of homogenates of skin punch biopsy specimens and supernatants of infected Vero cells that showed an evident cytopathic effect. Samples were frozen and thawed twice and centrifuged at $4,000 \times g$ for $20 \mathrm{~min}$ and at $9,300 \times g$ for $10 \mathrm{~min}$ to clarify the supernatant. The second supernatant $(82 \mu \mathrm{L})$ was then ultracentrifuged in an Airfuge centrifuge (Beckman Coulter, Brea, CA, USA) for $15 \mathrm{~min}$ at $21 \mathrm{lbs} /$ in $^{2}(82,000 \times g)$. The Airfuge was fitted with an A 100 rotor that held six $175-\mu \mathrm{L}$ test tubes containing specific adapters for 3-mm grids, which enables direct pelleting of virus particles on carbon-coated, formvar copper grids. These grids were stained with $2 \%$ sodium phosphotungstate, $\mathrm{pH} 6.8$, for 1.5 min, and observed with a Tecnai G2 Biotwin Transmission Electron Microscope (Field Electron and Ion Company, Hillsboro, OR, USA) operating at $85 \mathrm{kV}$. We identified poxvirus particles, observed at magnifications of $11,000 \times-26,500 \times$, on the basis of their typical morphologic characteristics.

\section{Serologic Analysis}

We tested the serum sample collected intravitam from the diseased cat for OPXV antibodies by virus neutralization and IIF assays. We used strains Italy_09/17 isolated from the same cat and VACV-WR in these tests.

For the virus neutralization test, we mixed 2-fold dilutions of heat-inactivated serum (starting at a dilution of $1: 2$ ) with $10050 \%$ tissue culture infective doses of virus in 96-well microtiter plates. After incubation at room temperature for $60 \mathrm{~min}, 2 \times 10^{4} \mathrm{CV}-1$ cells were added to each well. Plates were read after 4 days of incubation at $37^{\circ} \mathrm{C}$ in a humidified atmosphere of $5 \% \mathrm{CO}_{2}$.

For the IIF assay, we fixed confluent monolayers of CV-1 cells grown on coverslips and infected with strain
Italy_09/17 or VACV-WR with $80 \%$ acetone. We tested 2-fold dilutions of heat-inactivated serum (diluted 1:20 to $1: 5,120)$ by using 1 coverslip/dilution. Goat anti-cat IgG conjugated with fluorescein isothiocyanate was used as a secondary antibody (Sigma-Aldrich).

\section{Next-Generation Sequencing}

For DNA extraction, we obtained virus stocks from semipurified virus particles. In brief, we infected CV-1 cells with strain Italy_09/17. At 48 hours postinfection, the cell medium was collected and nuclei and cell debris were discarded by centrifugation at $1,000 \times g$ for $10 \mathrm{~min}$ at $4^{\circ} \mathrm{C}$. We extracted virus DNA by using a QIAamp Cador Pathogen Mini Kit (QIAGEN) according to the manufacturer's instructions.

We quantified DNA by using the Fluorometric Qubit dsDNA High Sensitivity Assay Kit (Thermo Fisher Scientific, Waltham, MA, USA). We prepared a genomic DNA library by using the Nextera DNA Sample Prep Kit (Illumina, San Diego, CA, USA) according to the manufacturer's protocol and performed a size-selection step manually by using Ampure XP magnetic beads (Beckman Coulter). We performed quality control analysis of the sample library by using the QIAxcel Advanced System with QIAxcel ScreenGel Software 1.4.0 (QIAGEN). We normalized library samples as suggested by QIAGEN and performed sequencing by using a MiSeq instrument, version 2, and a MiSeq Reagent Kit (Illumina).

\section{Genome Annotation and Comparison}

We obtained 1,497,762 paired reads in next-generation sequencing (NGS) experiments (Illumina); these reads had an average length of $155.4 \mathrm{bp}$. We performed quality control of reads by using FastQC (23) and sequence trimming by using the plugin Trim Ends in Geneious software version 10.1.3 (https://www.geneious.com/). We filtered NGS sequences by using the genome of African green monkey (Chlorocebus sabeus), which yielded 217,236 unmapped reads. We used these unmapped reads for de novo assembling of the feline OPXV genome by using the Geneious Assembler.

We annotated the nearly full-length genome sequence of the Italy_09/17 isolate by using ECTV strain Naval as reference (GenBank accession no. KJ563295). We performed genome annotation by using FindORFs software in Geneious version 10.1.3 and a set of reference sequences, including ECTV Naval (accession no. KJ563295), ECTV Mos (accession no. AF012825), CPXV BR (accession no. AF482758), and VACV COP (accession no. 35027) for comparison. We further analyzed open reading frames that remained unassigned or with a lower similarity to the reference sequences by using MyOrfeome (http://myorfeome.sourceforge.net). 


\section{Phylogenetic Analysis}

For characterization of the OPXV strain, we used the strategy proposed by Emerson et al. (24). We selected 9 coding sequences from the genome of the feline OPXV strain Italy 09/17: A7L, early transcription factor/VETF large subunit; A10L, major core protein; A24R, RNA polymerase 132; D1R, messenger RNA capping enzyme, large subunit; D5R, DNA-independent NTPase (DNA replication); E6R, hypothetical protein; E9L, DNA polymerase; H4L, RNA polymerase-associated protein; and J6R, RNA polymerase 147. Gene designations refer to the VACV COP genome. We aligned concatenated genome sequences of OPXVs representative of North American and Old World (African and Eurasian) viruses by using Geneious version 10.1.3 and the MAFFT algorithm (25). After searching the GenBank database, we retrieved complete HA gene sequences of 2 felinederived human OPXV strains (accession nos. EF612709 and FJ445747) and of an OPXV isolated from captive macaques (accession no. KY100116) and aligned them with cognate OPXV sequences.

We performed phylogenetic analysis for concatenated DNA alignments with Bayesian inference by using 4 chains run for $>1$ million generations $(26,27)$. We used ModelTest software (http://evomics.org/resources/software/ molecular-evolution-software/modeltest/) to identify the most appropriate model of evolution for the entire dataset and for each gene individually. The identified program settings for all partitions, under the Akaike Information Criteria, included 6 character states (general time reversible model), a proportion of invariable sites, and a gamma distribution of rate variation across sites. We deposited nucleotide sequences of strain Italy_09/17 used for phylogeny in GenBank (accession nos. MF578930-9).

\section{Detection of Other Pathogens}

We subjected nucleic acids extracted from freshly collected skin biopsy specimens and serum of the affected cat to a TaqMan assay for detection of canine parvovirus 2/feline panleukopenia virus (28) and to a minor groove binder probe assay for rapid discrimination between true feline panleukopenia virus strains and antigenic variants of canine parvovirus 2 (29). We also used DNA extracts to detect proviral DNA of feline immunodeficiency virus (30) and feline leukemia virus (31) and DNA of feline hemoplasmas (32) and feline herpesvirus (33). We screened RNA extracts by realtime PCR or conventional reverse transcription PCR specific for carnivore coronaviruses (34) and caliciviruses $(33,35)$.

\section{Results}

\section{Histopathologic Analysis}

Histopathologic analysis of multiple skin specimens showed mild hyperplasia of the epidermis and the follicular wall. Many roundish to oval brightly eosinophilic inclusion bodies were clearly evident in the cytoplasm of both epidermal and follicular keratinocytes, including in a few sebocytes. The morphology of cells suggested a possible OPXV infection (Figure 2, panel A). Nodular to diffuse dermatitis caused by mixed inflammatory cells was also present in dermis and hypodermis; those cells were mainly represented by eosinophils, histiocytes, and lymphocytes, together with few plasma cells and neutrophils.

\section{Molecular Investigations}

Molecular analysis of formalin-fixed, paraffin-embedded tissues showed positive results for the low GC panchordopoxvirus PCR and negative results for the high GC panchordopoxvirus PCR (19). This pattern of amplification was consistent with an OPXV infection. Amplification of the gene coding for the A-type inclusion protein generated an amplicon of $\approx 1,237 \mathrm{bp}$, and amplification of the HA gene $(20,21)$ generated an amplicon of $846 \mathrm{bp}$, which are expected sizes for these genes in ECTV. All samples collected from the cat were negative for other pathogens by the molecular assays used.

Sequence analysis of the HA gene of strain Italy_09/17 showed high nucleotide identity (98\%) with that of CPXV strain Germany (GenBank accession no. HQ420897) and to feline-derived human poxvirus IT1 (accession no. EF612709). In addition, strain Italy_09/17 was also highly related to most of the ECTV strains in GenBank; the highest (97\%) nucleotide identity was with ECTV strain Naval (accession no. KJ563295). Strain Italy_09/17 showed positive results in the ECTV-specific PCR and negative results in the CPXV-specific PCR (22) (Table 1).

\section{Virus Isolation}

Virus isolation from freshly collected skin biopsy specimens was successful with Vero and CV-1 cells. We observed a cytopathic effect at 48 hours postinfection that showed rounding of cells, increased granularity, and detachment from the monolayer. In Vero cells, a cytopathic effect was less evident than in CV-1 cells. Cells stained with hematoxylin and eosin contained large eosinophilic cytoplasmic inclusion bodies that were compatible with infection by poxviruses, including CPXV (36) and ECTV (37) (Figure 2, panel B).

The IIF assay showed granular fluorescence areas that displayed the morphology of the inclusion bodies in cell cytoplasms (Figure 2, panel C). Both CV-1 and Vero cells showed positive IIF assay results, but there was no fluorescence staining in the negative control.

At 48 hours postinoculation on embryonated eggs, virus produced superficial pocks on the chorioallantoic membrane. Most of these pocks were small (diameter 1.0 $\mathrm{mm})$, gray, and had central hemorrhages. Few $(3 \%-5 \%)$ 

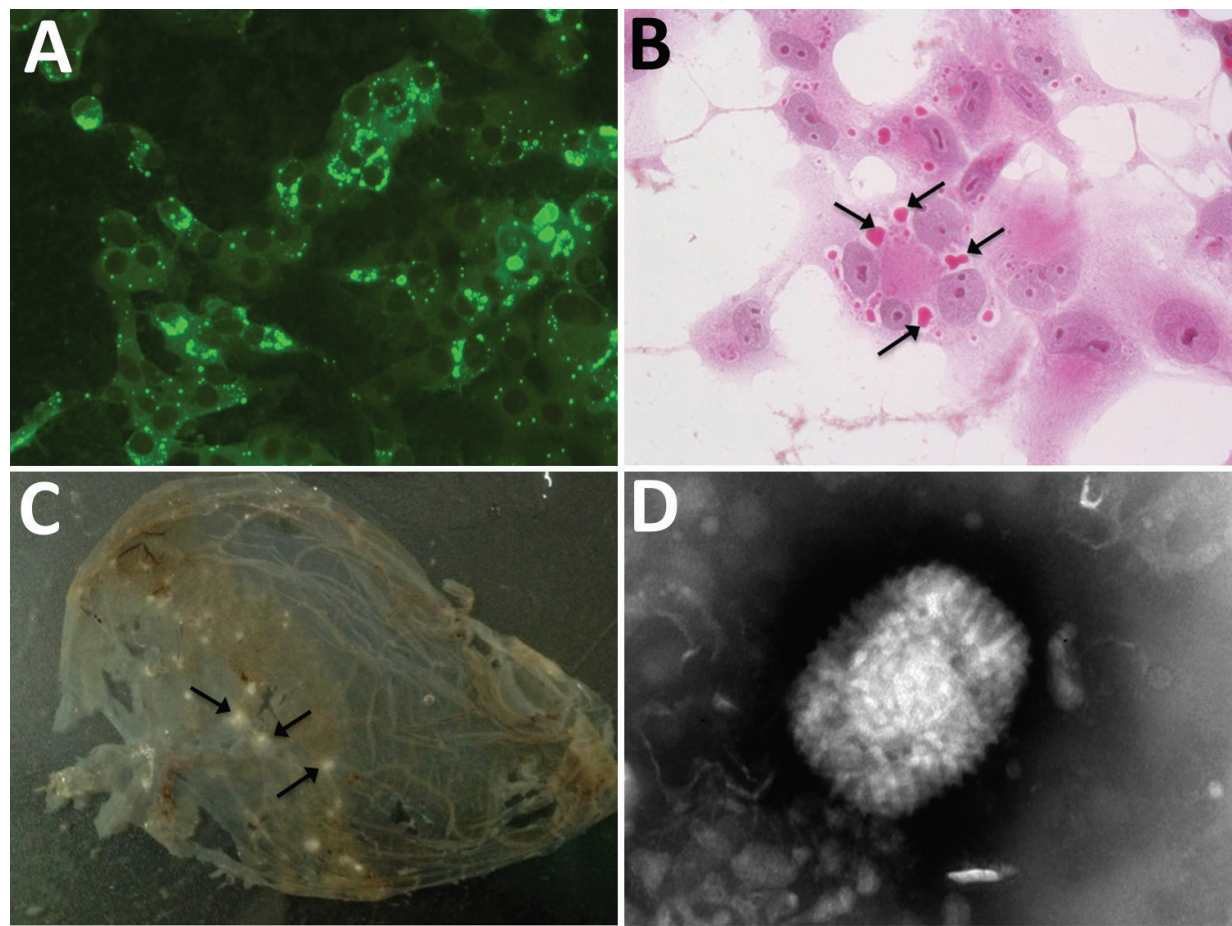

Figure 2. Analysis of an orthopoxvirus isolated from an infected cat, Italy. A) Cytoplasmic fluorescence in infected Vero cells using serum from the diseased cat (original magnification $\times 400$ ). B) Cytoplasmic inclusion bodies (arrows) in infected Vero cells (hematoxylin and eosin stain, original magnification $\times 400$ ). C) Pocks (arrows) in the inoculated chorioallantoic membrane of a 12-day-old chick embryo. D) Electron micrograph of orthopoxvirus-like particle from infected Vero cells. The virus preparation was negative-stained with sodium phosphotungstate (original magnification $\times 25,000$ ). pocks were larger (1.8 $\mathrm{mm}$ in diameter $)$, white, and without hemorrhages.

\section{Electron Microscopy}

Many typical brick-shaped virions $(\approx 320 \times 240 \mathrm{~nm})$ morphologically related to the genus Orthopoxvirus were observed by negative staining and electron microscopy. We observed these results for skin punch biopsy specimens and cell culture supernatants.

As in a previous study (15), few particles showed the characteristic ribbon structure of the $\mathrm{M}$ form of vaccinia virus (38) (Figure 2, panel D), which is usually prevalent in fresh preparations collected during acute-phase infections. Most virions were slightly larger, showed a uniform electron density, and had a thick capsule outlined by a ragged edge (i.e., the morphologic aspect known as the $\mathrm{C}$ form), which are less infective and prevalent during evolution of a chronic infection.

\section{Serologic Analysis}

The infected cat was negative by virus neutralization for strain Italy_09/17 and reference VACV isolates. However,

\begin{tabular}{|c|c|c|c|c|c|c|c|}
\hline Specificity & Target gene & Reference & Result & $\begin{array}{l}\text { Amplicon, } \\
\text { bp }\end{array}$ & Sequence & $\begin{array}{c}\text { First match by } \\
\text { BLAST analysis } \dagger\end{array}$ & $\begin{array}{l}\text { Nucleotide } \\
\text { identity, \% }\end{array}$ \\
\hline Panchordopoxvirus, low GC & $\begin{array}{c}\text { Insulin } \\
\text { metalloproteinase-like } \\
\text { protein gene/IMV } \\
\text { membrane protein } \\
\text { gene }\end{array}$ & (19) & + & 220 & + & $\begin{array}{l}\text { ECTV Naval } \\
\text { KJ563295 }\end{array}$ & 100 \\
\hline Panchordopoxvirus, high GC & $\begin{array}{c}\text { Insulin } \\
\text { metalloproteinase-like } \\
\text { protein gene/IMV } \\
\text { membrane protein } \\
\text { gene }\end{array}$ & (19) & ND & ND & ND & ND & ND \\
\hline Eurasian/African OPXVs & $\begin{array}{l}\text { A-type inclusion } \\
\text { protein gene }\end{array}$ & (20) & + & $1,237 \ddagger$ & + & $\begin{array}{l}\text { CPXV Germany } \\
91-3 \text { DQ437593 }\end{array}$ & 98 \\
\hline Eurasian/African OPXVs & Hemagglutinin gene & (21) & + & $864 \S$ & + & $\begin{array}{l}\text { Feline poxvirus } \\
\text { ITA2 FJ445747 }\end{array}$ & 96 \\
\hline ECTV & Hemagglutinin gene & (22) & + & 150 & + & $\begin{array}{l}\text { ECTV Naval } \\
\text { KJ563295 }\end{array}$ & 99 \\
\hline CPXV & Hemagglutinin gene & $(22)$ & ND & $629-677$ & ND & ND & ND \\
\hline
\end{tabular}

${ }^{*}$ CPXV, cowpox virus: ECTV, ectromelia virus; IMV, intracellular mature virus; ND, not determined; OPXV, orthopoxvirus; +, sequence obtained †https://blast.ncbi.nlm.nih.gov/Blast.cgi?PAGE_TYPE=BlastSearch. GenBank accession numbers are provided.

łExpected size for CPXV: 1,601 or $1,673 \mathrm{bp}$; expected size for ECTV: 1,220 bp.

§Expected size for CPXV: 942 bp; expected size for ECTV: 846 bp. 
the IIF assay detected antibody titers of 1:1,280 for virus Italy 09/17 and 1:640 for VACV-WR.

\section{Identification of a Novel OPXV by NGS}

We used 217,236 paired reads for de novo assembling and obtained 3 contigs (contig one, 195,015 bp; contig two, $21,014 \mathrm{bp}$; and contig three, 1,596 bp) and a quality score $>99 \%$. The mean coverage of the assembled contigs was $61 \times$. The 9 open reading frames (A7L, A10L, A24R, D1R, D5R, E6R, E9L, H4L, and J6R) used for OPXV characterization were mapped in contig 1 , and their sequences (total 27,228 nt) were concatenated and aligned with concatenated cognate sequences of selected OPXVs. In addition, because the HA gene of 2 feline-derived human virus isolates was available in the sequence databases, we performed an alignment based on the HA gene. We conducted phylogenetic analysis on the basis of the 9 concatenated sequences by using Bayesian inference. Posterior probabilities percentages were consistently high $(\geq 90 \%)$ for all clades on phylograms, which supported inferred phylogenetic relationships.

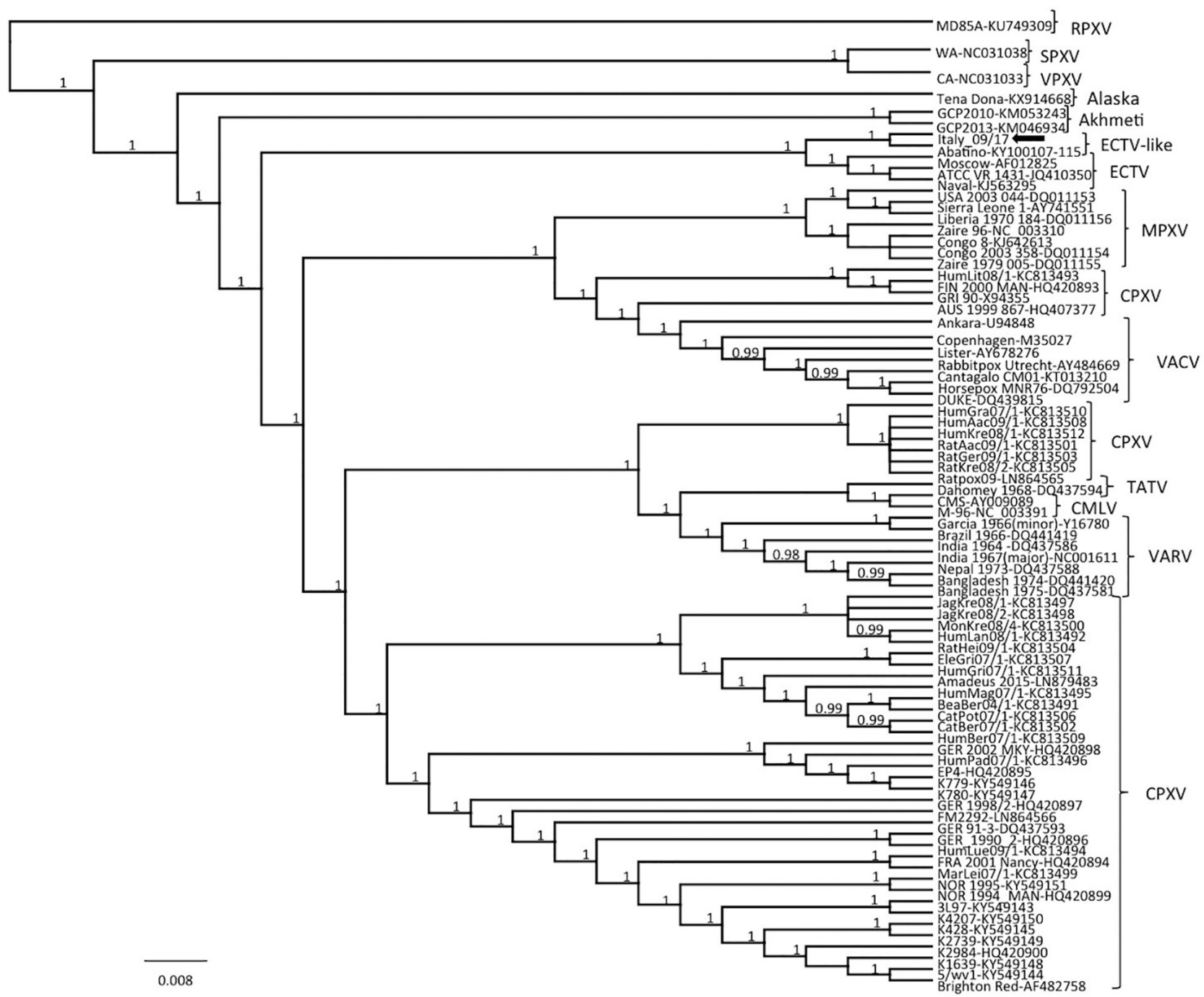

Figure 3. Phylogenetic relationship of extant orthopoxviruses with a feline poxvirus isolated from a cat, Italy. Phylogenetic tree shows 27,228 nt concatenated alignment of 9 coding gene (A7L, A10L, A24R, D1R, D5R, E6R, E9L, H4L, and J6R) sequences of orthopoxvirus. Gene designations refer to the VACV-COP genome (GenBank accession no. M35027). Posterior output of the tree was derived from Bayesian inference using 4 chains run for $>1$ million generations, a general time-reversible model, a proportion of invariable sites, a gamma distribution of rate variation across sites, and a subsampling frequency of 1,000 . Posterior probability values $>0.95$ are indicated on the tree nodes. The black arrow indicates the feline poxvirus Italy_09/17 isolated in this study. Raccoonpox virus strain MD85A was used as an outgroup. Strain name, host and year of detection, location of origin, and GenBank accession numbers for orthopoxviruses used for phylogeny are shown in Table 2 (https://wwwnc.cdc.gov/EID/article/24/9/17-1283-T2.htm). Scale bar indicates nucleotide substitutions per site. CMLV, camelpox virus; CPXV, cowpox virus; ECTV, ectromelia virus; MPXV, monkeypox virus; RPXV, raccoonpox virus; SPXV, skunkpox virus; TATV, taterapox virus; VACV, vaccinia virus; VARV, variola virus; VPXV, volepox virus. 
In the consensus phylogenetic tree (Figure 3), we found that strain Italy 09/17 was distantly related to other OPXVs, including all $10 \mathrm{CPXV}$ lineages (39) and other recently identified, deep-branching OPXVs $(40,41)$ and displayed a closer relatedness with ECTV prototypes, albeit forming a separate cluster. This cluster also included strain Abatino, which was recently isolated from a poxvirus outbreak in a captive colony of Tonkean macaques in Italy (42). Nucleotide identity of strain Italy_09/17 with strain Abatino was $99.66 \%$ and identity with reference ECTVs was $98.11 \%-98.13 \%$. Higher nucleotide identities were found among ECTVs (99.97\%-99.99\%) and between VARV-Garcia1966 (variola minor) and VARV-India1967 (variola major) (99.68\%). Thus, on the basis of current OPXV criteria of species demarcation, the cat and macaque isolates should be considered prototypes of a novel OPXV. Also, for the HA gene, strain Italy_09/17 appeared more closely related to strain Abatino (99.79\% nt identity) than to feline-derived human OPXV strains $(95.83 \%-95.99 \% \mathrm{nt}$ identity) that were identified in Italy in 2009, for which a full-length genome and concatenated genes used for species demarcation using phylogeny are not available (43).

\section{Discussion}

OPXV infection in cats is frequently observed, and OPXV transmission from cats to humans has been demonstrated or at least suspected on several occasions $(8,11,14,43-$ 47). Cats are susceptible to CPXV infection, for which they represent only incidental hosts, as are humans, cattle, horses, and dogs. The virus is usually transmitted to cats by hunted rodents; cat-to-cat transmission is apparently rare (47). In contrast, ECTV has a host range restricted to laboratory mice, and cat or human infections have not been reported $(6)$.

Additional OPXVs, such as raccoonpox virus and skunkpox virus, have been reported in wildlife and infect carnivores (48). Conversely, cats have been found to be susceptible to members of the genus Parapoxvirus, raccoonpox virus, and uncharacterized poxviruses (49). There are $>400$ reports of OPXV infection in domestic cats, but the total number of feline cases is considered to be much greater (5). Despite this large number of reports, genetic characterization of the detected poxvirus has been achieved in only a few instances. Thus, circulation in cats of other OPXVs cannot be ruled out.

We report detection of an OPXV strain that caused a fatal infection in a cat. The virus was not a classical CPXV, which is common in felids. Analysis of 9 concatenated genes showed that the poxvirus detected was only distantly related to all CPXV lineages currently known and formed a separate cluster with respect to ECTV, with which it was strictly related and grouped with an OPXV strain recently isolated from captive macaques in Italy (42). These 2 viruses had lower genetic identity with ECTV than that observed with reference ECTVs and between variola minor virus and variola major virus. Therefore, these ECTVlike poxviruses likely represent a novel OPXV species. However, the true animal reservoir of this novel OPXV needs to be assessed, and the idea that wild rodents can act as carriers for the new virus cannot be ruled out.

If one considers the close relatedness between strain Italy_09/17 and ECTV, which has been detected only in laboratory animals, it could be speculated that an ECTV-like virus circulating in wild rodents has resulted in ECTV strains adapted to laboratory mice. Alternatively, an ECTV strain might have escaped from laboratory mice and adapted to wild conditions. In addition, the zoonotic potential of the feline ECTV-like OPXV deserves an indepth investigation. Feline poxvirus was also related to an unclassified OPXV, which was detected in a human in Italy almost 10 years ago and for which only partial HA gene has been identified (43). Consequently, this feline poxvirus could represent a threat to human health. Thus, veterinarians and cat breeders and owners should be aware of this additional risk associated with handling of cats with skin lesions.

\section{Acknowledgments}

We thank Costantina Desario and Carlo Armenise for providing excellent technical assistance and G. Tekes for providing the VACV-WR strain and CV-1 cells.

This study was supported by grants from the University of Bari.

\section{About the Author}

Dr. Lanave is a postdoctoral fellow in the Department of Veterinary Medicine, University of Bari, Bari, Italy. His primary research interest is emerging viruses of animals.

\section{References}

1. Centers for Disease Control and Prevention. Bioterrorism agents/ diseases, 2015 [cited 2015 Nov 18] http://www.bt.cdc.gov/agent/ agentlist-category.asp

2. Reynolds MG, Carroll DS, Karem KL. Factors affecting the likelihood of monkeypox's emergence and spread in the post-smallpox era. Curr Opin Virol. 2012;2:335-43. http://dx.doi.org/ 10.1016/j.coviro.2012.02.004

3. Hendrickson RC, Wang C, Hatcher EL, Lefkowitz EJ. Orthopoxvirus genome evolution: the role of gene loss. Viruses. 2010;2:1933-67. http://dx.doi.org/10.3390/v2091933

4. Kinnunen PM, Henttonen H, Hoffmann B, Kallio ER, Korthase C, Laakkonen J, et al. Orthopox virus infections in Eurasian wild rodents. Vector Borne Zoonotic Dis. 2011;11:1133-40. http://dx.doi.org/10.1089/vbz.2010.0170

5. Essbauer S, Pfeffer M, Meyer H. Zoonotic poxviruses. Vet Microbiol. 2010;140:229-36. http://dx.doi.org/10.1016/ j.vetmic. 2009.08 .026

6. Esteban DJ, Buller RM. Ectromelia virus: the causative agent of mousepox. J Gen Virol. 2005;86:2645-59. http://dx.doi.org/ 10.1099/vir.0.81090-0 
7. Osterhaus AD, Teppema JS, Wirahadiredja RM, van Steenis G Mousepox in the Netherlands. Lab Anim Sci. 1981;31:704-6.

8. Vorou RM, Papavassiliou VG, Pierroutsakos IN. Cowpox virus infection: an emerging health threat. Curr Opin Infect Dis. 2008;21:153-6. http://dx.doi.org/10.1097/QCO.0b013e3282f44c74

9. Schaudien D, Meyer H, Grunwald D, Janssen H, Wohlsein P. Concurrent infection of a cat with cowpox virus and feline parvovirus. J Comp Pathol. 2007;137:151-4. http://dx.doi.org/ 10.1016/j.jcpa.2007.05.007

10. Schöniger S, Chan DL, Hollinshead M, Humm K, Smith GL, Beard PM. Cowpox virus pneumonia in a domestic cat in Great Britain. Vet Rec. 2007;160:522-3. http://dx.doi.org/10.1136/ vr.160.15.522

11. Schulze C, Alex M, Schirrmeier H, Hlinak A, Engelhardt A, Koschinski B, et al. Generalized fatal Cowpox virus infection in a cat with transmission to a human contact case. Zoonoses Public Health. 2007;54:31-7. http://dx.doi.org/10.1111/ j.1863-2378.2007.00995.x

12. Johnson MS, Martin M, Stone B, Hetzel U, Kipar A. Survival of a cat with pneumonia due to cowpox virus and feline herpesvirus infection. J Small Anim Pract. 2009;50:498-502. http://dx.doi.org/ 10.1111/j.1748-5827.2009.00784.x

13. Kaysser P, von Bomhard W, Dobrzykowski L, Meyer H. Genetic diversity of feline cowpox virus, Germany 2000-2008. Vet Microbiol. 2010;141:282-8. http://dx.doi.org/10.1016/ j.vetmic.2009.09.029

14. Herder V, Wohlsein P, Grunwald D, Janssen H, Meyer H, Kaysser $\mathrm{P}$, et al. Poxvirus infection in a cat with presumptive human transmission. Vet Dermatol. 2011;22:220-4. http://dx.doi.org/10.1111/j.1365-3164.2010.00947.x

15. Canese MG, Lavazza A, Massone A, Galeano F, Boldini M. Feline poxvirus infection. A case report. Schweiz Arch Tierheilkd. 1997;139:454-7.

16. Haenssle HA, Kiessling J, Kempf VA, Fuchs T, Neumann C, Emmert S. Orthopoxvirus infection transmitted by a domestic cat. J Am Acad Dermatol. 2006;54(Suppl):S1-4. http://dx.doi.org/ 10.1016/j.jaad.2005.09.040

17. Schiavi S, Vercelli A, Abtamo FU. A case of viral poxvirus dermatitis in a cat [in Italian]. Presented at the Congress of the Italian Society of Veterinary Dermatology; March 11, 2007; Cremona, Italy.

18. Appl C, von Bomhard W, Hanczaruk M, Meyer H, Bettenay S, Mueller R. Feline cowpoxvirus infections in Germany: clinical and epidemiological aspects. Berl Munch Tierarztl Wochenschr. 2013;126:55-61.

19. Li Y, Meyer H, Zhao H, Damon IK. GC content-based pan-pox universal PCR assays for poxvirus detection. J Clin Microbiol. 2010;48:268-76. http://dx.doi.org/10.1128/JCM.01697-09

20. Meyer H, Ropp SL, Esposito JJ. Gene for A-type inclusion body protein is useful for a polymerase chain reaction assay to differentiate orthopoxviruses. J Virol Methods. 1997;64:217-21. http://dx.doi.org/10.1016/S0166-0934(96)02155-6

21. Ropp SL, Jin Q, Knight JC, Massung RF, Esposito JJ. Polymerase chain reaction strategy for identification and differentiation of smallpox and other orthopoxviruses. J Clin Microbiol. 1995;33:2069-76.

22. Meyer H, Damon IK, Esposito JJ. Orthopoxvirus diagnostics. Methods Mol Biol. 2004;269:119-34.

23. Andrews S. FastQC: a quality control tool for high throughput sequence data, 2010 [cited 2018 May 15]. http://www.bioinformatics.bbsrc.ac.uk/projects/fastqc/

24. Emerson GL, Li Y, Frace MA, Olsen-Rasmussen MA, Khristova ML, Govil D, et al. The phylogenetics and ecology of the orthopoxviruses endemic to North America. PLoS One. 2009;4:e7666. http://dx.doi.org/10.1371/journal.pone.0007666

25. Katoh K, Misawa K, Kuma K, Miyata T. MAFFT: a novel method for rapid multiple sequence alignment based on fast Fourier transform. Nucleic Acids Res. 2002;30:3059-66. http://dx.doi.org/10.1093/nar/gkf436

26. Huelsenbeck JP, Ronquist F. MRBAYES: Bayesian inference of phylogenetic trees. Bioinformatics. 2001;17:754-5. http://dx.doi.org/10.1093/bioinformatics/17.8.754

27. Ronquist F, Huelsenbeck JP. MrBayes 3: Bayesian phylogenetic inference under mixed models. Bioinformatics. 2003;19:1572-4. http://dx.doi.org/10.1093/bioinformatics/btg180

28. Decaro N, Elia G, Martella V, Desario C, Campolo M, Trani LD, et al. A real-time PCR assay for rapid detection and quantitation of canine parvovirus type 2 in the feces of dogs. Vet Microbiol. 2005;105:19-28. http://dx.doi.org/10.1016/ j.vetmic.2004.09.018

29. Decaro N, Desario C, Lucente MS, Amorisco F, Campolo M, Elia G, et al. Specific identification of feline panleukopenia virus and its rapid differentiation from canine parvoviruses using minor groove binder probes. J Virol Methods. 2008;147:67-71. http://dx.doi.org/10.1016/j.jviromet.2007.08.006

30. Stiles J, Bienzle D, Render JA, Buyukmihci NC, Johnson EC. Use of nested polymerase chain reaction (PCR) for detection of retroviruses from formalin-fixed, paraffin-embedded uveal melanomas in cats. Vet Ophthalmol. 1999;2:113-6. http://dx.doi.org/10.1046/j.1463-5224.1999.00066.x

31. Quackenbush SL, Dean GA, Mullins JI, Hoover EA. Analysis of FeLV-FAIDS provirus burden and productive infection in lymphocyte subsets in vivo. Virology. 1996;223:1-9. http://dx.doi.org/10.1006/viro.1996.0449

32. Tasker S, Binns SH, Day MJ, Gruffydd-Jones TJ, Harbour DA, Helps CR, et al. Use of a PCR assay to assess the prevalence and risk factors for Mycoplasma haemofelis and 'Candidatus Mycoplasma haemominutum' in cats in the United Kingdom. Vet Rec. 2003;152:193-8. http://dx.doi.org/10.1136/vr.152.7.193

33. Di Martino B, Di Francesco CE, Meridiani I, Marsilio F. Etiological investigation of multiple respiratory infections in cats. New Microbiol. 2007;30:455-61.

34. Gut M, Leutenegger CM, Huder JB, Pedersen NC, Lutz H. One-tube fluorogenic reverse transcription-polymerase chain reaction for the quantitation of feline coronaviruses. J Virol Methods. 1999;77:37-46. http://dx.doi.org/10.1016/ S0166-0934(98)00129-3

35. Jiang X, Huang PW, Zhong WM, Farkas T, Cubitt DW, Matson DO. Design and evaluation of a primer pair that detects both Norwalkand Sapporo-like caliciviruses by RT-PCR. J Virol Methods. 1999;83:145-54. http://dx.doi.org/10.1016/S0166-0934(99)00114-7

36. Downie AW. A study of the lesions produced experimentally by cowpox virus. J Pathol Bacteriol. 1939;48:361-79. http://dx.doi.org/10.1002/path.1700480212

37. Barnard JE, Elford WJ. The causative organism in infectious ectromelia. Proceedings of the Royal Society, Series B. 1931;109:360-80. http://dx.doi.org/10.1098/rspb.1931.0088

38. Westwood JC, Harris WJ, Zwartouw HT, Titmuss DH, Appleyard G. Studies on the structure of vaccinia virus. J Gen Microbiol. 1964;34:67-78. http://dx.doi.org/10.1099/ 00221287-34-1-67

39. Mauldin MR, Antwerpen M, Emerson GL, Li Y, Zoeller G, Carroll DS, et al. Cowpox virus: what's in a name? Viruses. 2017;9:E101. http://dx.doi.org/10.3390/v9050101

40. Springer YP, Hsu CH, Werle ZR, Olson LE, Cooper MP, Castrodale LJ, et al. Novel orthopoxvirus infection in an Alaska resident. Clin Infect Dis. 2017;64:1737-41. http://dx.doi.org/ 10.1093/cid/cix219

41. Vora NM, Li Y, Geleishvili M, Emerson GL, Khmaladze E, Maghlakelidze G, et al. Human infection with a zoonotic orthopoxvirus in the country of Georgia. N Engl J Med. 2015;372:1223-30. http://dx.doi.org/10.1056/NEJMoa1407647 
42. Cardeti G, Gruber CEM, Eleni C, Carletti F, Castilletti C, Manna G, et al. Fatal outbreak in Tonkean macaques caused by possibly novel orthopoxvirus, Italy, January 2015. Emerg Infect Dis. 2017;23:1941-9. http://dx.doi.org/10.3201/ eid2312.162098

43. Carletti F, Bordi L, Castilletti C, Di Caro A, Falasca L, Gioia C, et al. Cat-to-human orthopoxvirus transmission, northeastern Italy. Emerg Infect Dis. 2009;15:499-500. http://dx.doi.org/10.3201/ eid1503.080813

44. Eis-Hübinger AM, Gerritzen A, Schneweis KE, Pfeiff B, Pullmann H, Mayr A, et al. Fatal cowpox-like virus infection transmitted by cat. Lancet. 1990;336:880. http://dx.doi.org/ 10.1016/0140-6736(90)92387-W

45. Schupp P, Pfeffer M, Meyer H, Burck G, Kölmel K, Neumann C. Cowpox virus in a 12-year-old boy: rapid identification by an orthopoxvirus-specific polymerase chain reaction. Br J Dermatol. 2001;145:146-50. http://dx.doi.org/ 10.1046/j.1365-2133.2001.04300.x
46. Hawranek T, Tritscher M, Muss WH, Jecel J, Nowotny N, Kolodziejek J, et al. Feline orthopoxvirus infection transmitted from cat to human. J Am Acad Dermatol. 2003;49:513-8. http://dx.doi.org/10.1067/S0190-9622(03)00762-X

47. Świtaj K, Kajfasz P, Kurth A, Nitsche A. Cowpox after a cat scratch: case report from Poland. Ann Agric Environ Med. 2015;22:456-8. http://dx.doi.org/10.5604/12321966.1167713

48. International Committee on Taxonomy of Viruses. Virus taxonomy: 2016 release, 2017 [cited 2018 May 15]. https://talk.ictvonline.org/ taxonomy/

49. Greene CE. Poxvirus infections. In: Greene CE, editor. Infectious diseases of the dog and cat. 4th ed. St. Louis: Saunders Elsevier; 2006. p. 166-9.

Address for correspondence: Nicola Decaro, Department of Veterinary Medicine, University of Bari, Strada Provinciale per Casamassima Km 3, 70010 Valenzano, Bari, Italy; email: nicola.decaro@uniba.it.

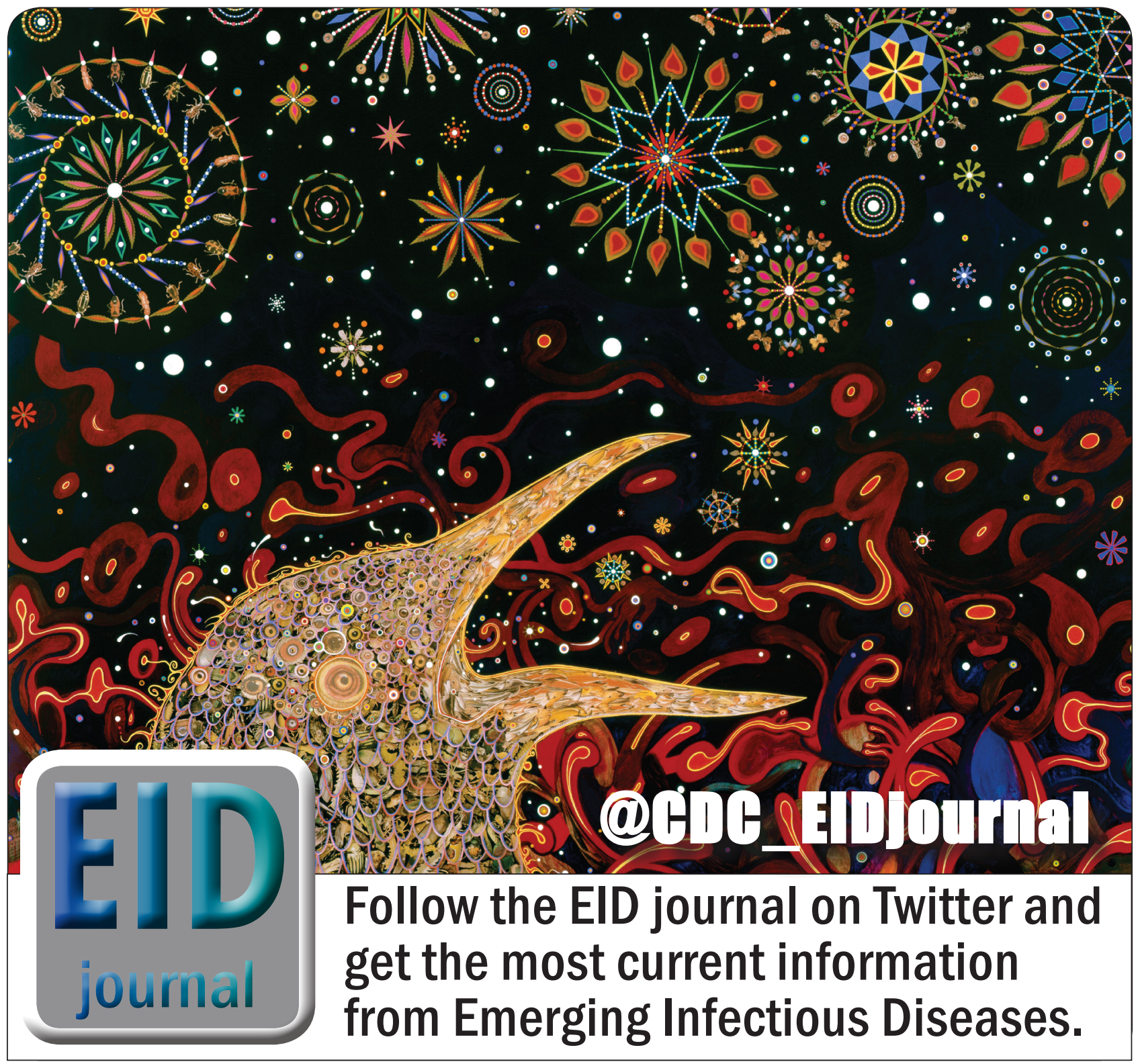

